\title{
MODELLING OF THE SUGAR BEET PULP DRYING PROCESS
}

\author{
ADINA GHIRIŞAN ${ }^{a}$, SIMION DRĂGAN ${ }^{a}$, CONSTANTIN COTA ${ }^{b}$, \\ ELENA-MIHAELA NAGY ${ }^{b}$, GYORGY ZOLTAN ${ }^{b}$, VASILE MICLĂUŞ ${ }^{a *}$
}

\begin{abstract}
The paper presents the drying model proposed for sugar beet pulp in the presence of hydrated lime within a range temperature of 333 and $368 \mathrm{~K}$. The experimental results were used to identify the coefficients in the two-term exponential model, choose as the most appropriated model for our case. The relationships for the variation of the coefficients with temperature were determined. The equations of the mathematical model were used to establish the optimal drying time.
\end{abstract}

Keywords: sugar beet pulp, drying kinetics, drying rate, mathematical modeling

\section{INTRODUCTION}

The sugar beet pulp represents the fibrous material which results as a by-product in the sugar manufacturing process. It is a macromolecular product of the sugar beet cellular membrane made of protopectin, with a high content of proteins, vitamins and minerals, essential elements for the health of animals [1].

The presence of the sugar beet pulp in the feed of ruminants leads to positive effects as: the substitution of grains for lactating dairy cattle, the increase of milk production and fat content, the reduction of pollutants $\left(\mathrm{CO}_{2}, \mathrm{CH}_{4}\right)$ during digestion, the improving of metabolic health of animals, etc. [2-9].

The efficiency of the sugar beet pulp in animal feed can be substantially improved by the addition of macro and microelements $\left(\mathrm{Ca}^{2+}, \mathrm{Mg}^{2+} \mathrm{PO}_{4}{ }^{3-}\right)$, respectively $\left(\mathrm{Co}^{2+}, \mathrm{Zn}^{2+}, \mathrm{Mn}^{2+}\right)$, the additional administration of $\mathrm{Ca}^{2+}$ leading to easy assimilable compounds. In this context the addition of $\mathrm{Ca}^{2+}$ in the

\footnotetext{
a Babeş-Bolyai University, Faculty of Chemistry and Chemical Engineering, 11 Arany Janos str., RO-400028, Cluj-Napoca, Romania

b Institutul Naţional de Cercetare - Dezvoltare Pentru Maşini şi Instalaţii Destinate Agriculturii şi Industriei Alimentare, Sucursala Cluj-Napoca, Str. Al. Vaida-Voievod, Nr. 59, RO-400458, Romania

*Corresponding authormiclausv@yahoo.com
} 
form of hydrated lime $\mathrm{Ca}(\mathrm{OH})_{2}$ in the sugar beet pulp subjected to drying leads to the formation of organo-mineral complexes in which the assimilation is superior to that of carbonates [10].

These products with high perishable cannot be stored for longer periods of time. So, their processing is required in order to ensure the properties maintenance. Drying of the sugar beet pulp, as the most common form of preservation, is imposed too, by the seasonal functioning character of the sugar factories, when it results in large quantities that cannot be used in full [11].

In the literature, different mathematical models are proposed, in order to fit the experimental measurements (see Table 1).

Table 1. Thin layer drying models $[12,13]$

\begin{tabular}{|l|l|l|}
\hline \multicolumn{1}{|c|}{ Model name } & \multicolumn{1}{c|}{ Model equation } & \multicolumn{1}{c|}{ References } \\
\hline Exponential model & $\mathrm{MR}=\exp (-\mathrm{kt})$ & El-Beltagy et al. (2007) \\
\hline Generalized exponential model & $\mathrm{MR}=\mathrm{Aexp}(-\mathrm{kt})$ & Shittu and Raji (2008) \\
\hline Logarithmic model & $\mathrm{MR}=\operatorname{aexp}(-\mathrm{kt})+\mathrm{C}$ & Akpinar and Bicer (2008) \\
\hline Page's model & $\mathrm{MR}=\exp \left(-\mathrm{kt}^{\mathrm{n}}\right)$ & Singh et al. (2008) \\
\hline Midilli-Kucuk model & $\mathrm{MR}=\mathrm{aexp}\left(-\mathrm{kt}^{\mathrm{n}}\right)+\mathrm{bt}$ & Midilli and Kucuk (2003) \\
\hline Parabolic model & $\mathrm{MR}=\mathrm{a}+\mathrm{bt}+\mathrm{ct}^{2}$ & Doymaz (2010) \\
\hline Two-term exponential & $\mathrm{MR}=\mathrm{A}_{1} \mathrm{e}^{\mathrm{K} 1 \mathrm{t}+\mathrm{A}_{2} \mathrm{e}^{\mathrm{K} 2 \mathrm{t}}}$ & Henderson (1974) \\
\hline
\end{tabular}

In the present work, a mathematical model was developed based on the drying kinetic data of sugar beet pulp, considering the influence of drying temperature and the addition of hydrated lime. The proposed model allows the calculation of the drying time, in order to reach a certain moisture content that will allow the storage without alteration.

\section{RESULTS AND DISCUSSION}

Solving the main engineering problems of the drying process, choosing and sizing the dryer, automation, optimization and computerized management, implies to know the mathematical model after which it is carried out. There are two methods to establish the model that show the evolution in time of a physical or chemical process:

- Theoretical modelling, which assumes that the kinetic equation of the studied phenomenon is known;

- Empirical modelling that involves experimental measurements of the rates, the numerical values obtained being subsequently correlated in a kinetic equation. 
The large number of parameters that influence the drying, as well as the large number of phenomena that occur during the drying process (internal and external diffusion of water vapours, thermal transfer from the drying agent to the material or through the crust of solid material, mass transformation processes, water evaporation, desorption, etc.) makes theoretical modelling difficult to access.

Modelling of drying process can be carried out not only after simple models but also after a combined model, when two or even three elementary processes have the rates of the same order of magnitude [14]. Therefore, in the case of solids drying, empirical modelling is required. These models implied experimental measurements in conditions as close to those to be used in industrial practice [15-19].

The experimental values of the moisture content $\mathrm{M}_{\mathrm{t}}$, calculated by Equation 1, are processed first as a function of time in the form of drying curves (Figure 1).

$$
M_{t}=\frac{m_{i}-m_{t}}{m}=\frac{m_{i}\left(X_{i}-X_{t}\right)}{m_{i}\left(1-X_{i}\right)}=\frac{X_{i}-X_{i} \cdot \eta}{1-X_{i}}
$$

where: $\mathrm{M}_{\mathrm{t}}$ is the moisture content at any drying time (Kg water $/ \mathrm{Kg}$ dry material); $m_{i}-$ the initial mass of the sample $(\mathrm{Kg}) ; m_{t}-$ the mass of sample at any time $t$ $(\mathrm{Kg}) ; \mathrm{m}$ - the mass of the dry material $(\mathrm{Kg}) ; \eta$ - degree of moisture removal; $X_{i}$ the fraction of the initial water content; $X_{t}$ - the fraction of the water content at any drying time.

In Figure 1, the influence of the temperature on the drying was performed comparatively for the raw sugar beet pulp (P1) and the sugar beet pulp with the addition of $\mathrm{Ca}(\mathrm{OH})_{2}(\mathrm{P} 2)$.

The analysis of the drying curves shows that the drying occurs during the falling-rate period for both cases, the diffusion of the moisture from inside to the surface of material being the limitative process.

The drying results show the strong influence of the temperature on the time required for the total remove of the moisture, Table 2.

Table 2. The time required for the total removal of the moisture

\begin{tabular}{|c|c|c|c|c|}
\hline \multirow{2}{*}{ Sample } & \multicolumn{4}{|c|}{ Time, s } \\
\cline { 2 - 5 } Temperature, $[\mathrm{KT}$ & 333 & 343 & 358 & 368 \\
\hline $\mathrm{P} 1$ & 5500 & 4500 & 3360 & 2400 \\
\hline $\mathrm{P} 2$ & 3800 & 2250 & 1700 & 1650 \\
\hline
\end{tabular}


ADINA GHIRIŞAN, SIMION DRĂGAN, CONSTANTIN COŢA, ELENA-MIHAELA NAGY, GYORGY ZOLTAN, VASILE MICLĂUŞ

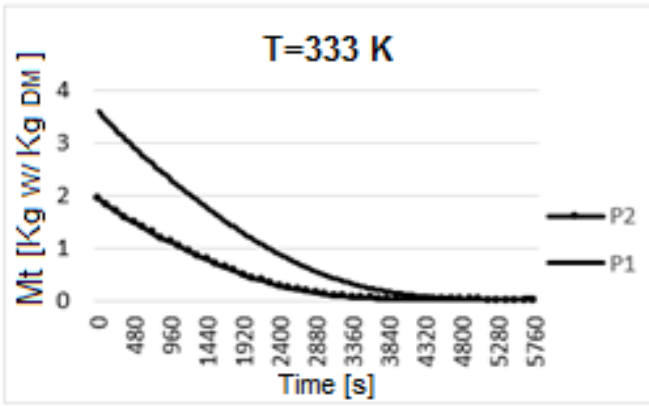

a



C

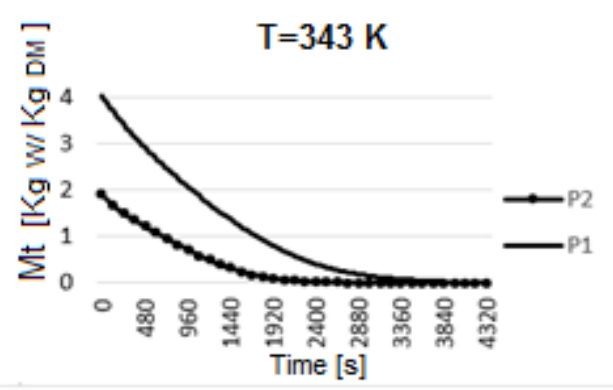

b

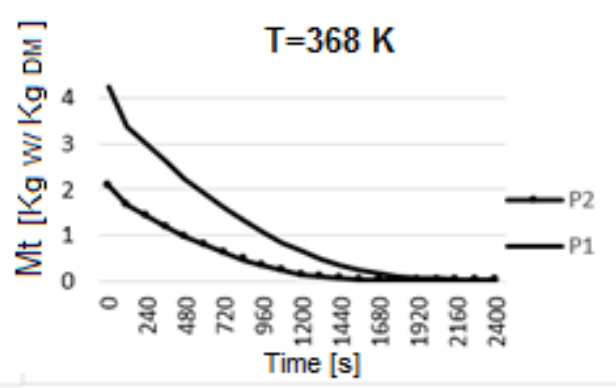

d

Figure 1. Evolution of moisture content in time at temperatures of:

$$
\text { a) } \mathrm{T}=333 \mathrm{~K} \text {; b) } \mathrm{T}=343 \mathrm{~K} \text {; c) } \mathrm{T}=358 \mathrm{~K} \text {; d) } \mathrm{T}=368 \mathrm{~K}
$$

The curves from Figure 1 show too, the positive influence the addition of $\mathrm{Ca}(\mathrm{OH})_{2}$ on the time required for the total removal of moisture. At each thermal regime, for samples with the addition of $\mathrm{Ca}(\mathrm{OH})_{2}$, the total removal time is reduced with $30-40 \%$.

The validation of the mathematical model implies the identification of the coefficients. For the two-term exponential model, used in the present analysis, the numerical values of the $\mathrm{K}$ and $\mathrm{A}$ coefficients obtained by the mathematical processing of the experimental are presented in Table 3.

The values of $A$ and $K$ coefficients increase with temperature, in both cases for sample $\mathrm{P} 1$ and for $\mathrm{P} 2$.

The evolution of the drying rate over the time determined with the experimental data using the finite difference method, and those obtained by the equation of the mathematical model are shown in Figure 2.

The drying rate was calculated as follows:

$$
\mathrm{r}=\frac{\mathrm{M}_{\mathrm{t}}-\mathrm{M}_{\mathrm{t}+\mathrm{dt}}}{\mathrm{dt}}
$$


where: $r$ is the drying rate $\left(\mathrm{Kg}\right.$ water $/ \mathrm{Kg}$ dry material. $\left.\mathrm{m}^{2} . \mathrm{h}\right), \mathrm{M}_{\mathrm{t}}$ is the moisture content at time $\mathrm{t}\left(\mathrm{Kg}\right.$ water $/ \mathrm{Kg}$ dry material); $\mathrm{M}_{\mathrm{t+dt}}$ - the moisture content at $\mathrm{t}+\mathrm{dt}$ (Kg water/ Kg dry material); and $\mathrm{t}$ - time ( $\mathrm{h}$ ).

Table 3. The numerical values of the coefficients for two-term exponential model

\begin{tabular}{|c|c|c|c|c|c|}
\hline \multirow{2}{*}{ Coefficient } & $\begin{array}{r}\mathrm{T}[\mathrm{K}] \\
\text { Sample }\end{array}$ & \multirow{2}{*}{333} & 343 & 358 & 368 \\
\hline \multirow{2}{*}{$\mathrm{K}_{1}$} & $\mathrm{P} 1$ & 0.985 & 1.770 & 2.900 & 3.705 \\
\cline { 2 - 6 } & $\mathrm{P} 2$ & 1.250 & 2.330 & 3.020 & 4.030 \\
\hline \multirow{2}{*}{$\mathrm{K}_{2}$} & $\mathrm{P} 1$ & 3.750 & 6.150 & 6.470 & 12.390 \\
\cline { 2 - 6 } & $\mathrm{P} 2$ & 5.510 & 9.790 & 10.710 & 16.370 \\
\hline \multirow{2}{*}{$\mathrm{A}_{1}$} & $\mathrm{P} 1$ & 6.780 & 7.270 & 7.650 & 7.910 \\
\cline { 2 - 6 } & $\mathrm{P} 2$ & 6.330 & 6.820 & 7.040 & 7.350 \\
\hline \multirow{2}{*}{$\mathrm{A}_{2}$} & $\mathrm{P} 1$ & 9.390 & 9.940 & 9.123 & 11.090 \\
\cline { 2 - 6 } & $\mathrm{P} 2$ & 9.020 & 10.030 & 9.770 & 10.820 \\
\hline
\end{tabular}

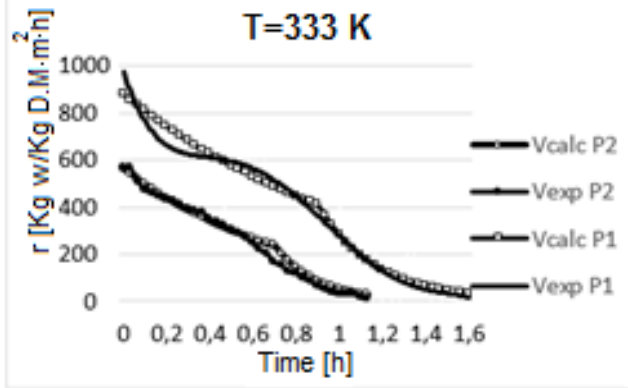

a

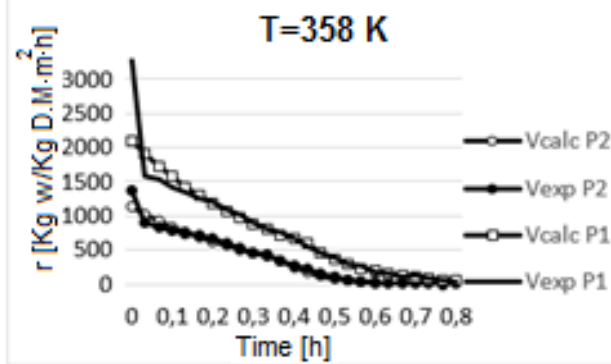

C



b

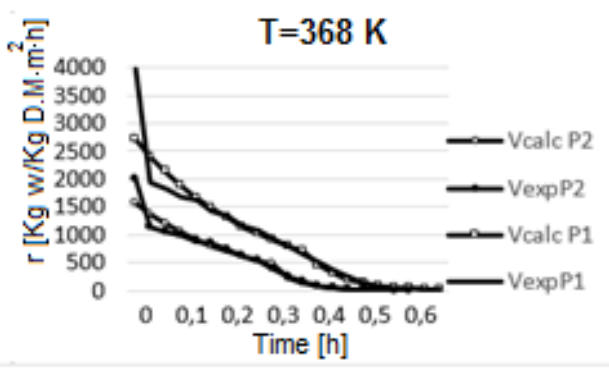

d

Figure 2. The comparative values of the drying rate resulted from experimental measurements with those calculated by the proposed model 
Validation of the proposed mathematical model by means of the numerical values of the $\mathrm{K}$ and $\mathrm{A}$ coefficients, has shown that the drying rate determined experimentally does not agree with the one calculated with the proposed equation, during the entire process. Thus, at degrees of moisture removal greater than $90 \%$ $(+/-1.5 \%)$ it is observed that takes place the modification of the mechanism, during the remove of the moisture. There are two areas:

- a) first area corresponds to the time interval until the elimination of approx. $90 \%(+/-1.5 \%)$ of the total moisture content of the material. This drying period is carried out at a rate corresponding to the values $K_{1}$ and $A_{1}$ from the proposed mathematical model. The duration of this period is $t_{1}$;

- b) second area corresponds to the elimination of the rest of approx. $10 \%$ of the total moisture of the material. This area is characterized by the numerical values $K_{2}$ and $A_{2}$ of the proposed mathematical model and corresponds to the duration of development $t_{2}$. The time required to eliminate the total moisture is obtained by summing the time for the two areas: $t_{t}=t_{1}+t_{2}$.

Comparing the experimental measurements results of the drying rate with those calculated on the basis of the mathematical model (Figure 2) it was found a good agreement in the temperature range 343-368 K. At the temperature of $333 \mathrm{~K}$ there are deviations that correspond to a certain moisture content of the sugar beet pulp. This deviation is determined by the more complex mechanism of the drying process, mainly determined by the complex porous structure of the sugar beet pulp.

At low temperatures, the cell walls membranes are less destroyed in time. That determines the existence of pores of different sizes in which the water is retained with different forces, hence the different drying rate. At temperatures higher than $333 \mathrm{~K}$, at samples with lime addition, macro-pores are formed from the first moments of the process, which causes the elimination of water to be done by simpler mechanisms.

Determining the time required for drying at temperatures other than those at which experimental measurements have been made requires establishing the temperature dependence of the $\mathrm{K}$ coefficients of the mathematical model. The mathematical processing of the numerical values in Table 3 leads to the equations presented in Table 4.

Table 4. The equations for the coefficients $\mathrm{K}$ depending on the temperature range

\begin{tabular}{|c|c|c|}
\hline \multirow{3}{*}{ Sample } & \multicolumn{2}{|c|}{ Equations for the coefficient $\mathrm{K}$ calculation } \\
\cline { 2 - 3 } & $\begin{array}{c}\text { Validity range } \\
\eta=0-0.9\end{array}$ & $\begin{array}{c}\text { Validity range } \\
\eta=0.9-1\end{array}$ \\
\hline $\mathrm{P} 1$ & $\mathrm{~K}_{11}=0.85+0.0816^{*} \Delta \mathrm{T}$ & $\mathrm{K}_{12}=3.75+0.247^{*} \Delta \mathrm{T}$ \\
\hline $\mathrm{P} 2$ & $\mathrm{~K}_{21}=1.25+0.0794^{*} \Delta \mathrm{T}$ & $\mathrm{K}_{22}=5.51+0.310^{*} \Delta \mathrm{T}$ \\
\hline
\end{tabular}

where: $\Delta \mathrm{T}=\mathrm{T}_{\mathrm{i}}-333$

$\mathrm{T}=$ temperature in the range $333-368 \mathrm{~K}$. 
By combining Equation (1) with Equation of drying rate (2), as well as with those which reproduce the variation of the coefficients with the temperature (Table 4), one can obtain the relationships which allow the determination of the drying time for temperatures other than those for which were performed experimentally (Equations 3 and 4 ).

$$
\begin{aligned}
& \frac{X_{t}-X_{t} \cdot \eta}{1-X_{t}}=7,11 \cdot e^{-(0,85+0,0816 \cdot \Delta I)}+9,49 \cdot e^{-(9 ; .75+0,247 \cdot \Delta T)} \\
& \frac{X_{t}-X_{L} \cdot \eta}{1-X_{t}}=6,88 \cdot e^{-(1,25+0,0794 \cdot \Delta T)}+9,61 \cdot e^{-(5,51+0,3 \cdot 1 \cdot \Delta T)}
\end{aligned}
$$

\section{CONCLUSIONS}

The study of the sugar beet pulp drying has shown that the addition of $\mathrm{Ca}(\mathrm{OH})_{2}$ leads to the breakdown of the cell walls of the sugar beet pulp which caused the acceleration of the process.

The mathematical models for the drying of raw sugar beet pulp and in the presence of lime were developed.

From the experimental measurements data, the coefficients $K_{1}$ and $\mathrm{K}_{2}$ used in the proposed model equations were calculated.

The numerical values of the $\mathrm{K}$ coefficients allow to establishing their variation equations with the temperature, and forward to apply the developed equation in the case of other process temperatures.

The equations established for the drying time calculation necessary to remove a certain amount of moisture are presented.

\section{EXPERIMENTAL SECTION}

The experiments were performed using industrial sugar beet pulp resulting from the TEREOS-Ludus sugar factory, Romania.

The source for $\mathrm{Ca}^{2+}$ ions was hydrated lime $\mathrm{Ca}(\mathrm{OH})_{2}$ obtained in laboratory by hydrating the industrial lime used in sugar factories.

The experimental study of drying was carried out with an AXIS-100 moisture analyzer with natural convection and maximum capacity of $100 \mathrm{~g}$ at the weighing accuracy of $0.01 \%$. The heat contribution required for the evaporation of water is achieved by means of two halogen lamps with which the moisture analyzer is provided. The moisture analyzer is provided too, with an automatic temperature control system and the software for automatically measuring of the sample mass in time. Its software allows the collection and storage of measured values on the PC connected to the moisture analyzer. 
ADINA GHIRIŞAN, SIMION DRĂGAN, CONSTANTIN COŢA, ELENA-MIHAELA NAGY, GYORGY ZOLTAN, VASILE MICLĂUŞ

The sample $\mathrm{P} 1$ contained $18.7 \%$ dried organic substances. The sample $\mathrm{P} 2$ contained $30 \%$ of $\mathrm{CaO}$, reported to the dried material.

\section{ACKNOWLEDGMENTS}

This work was supported by a grant of the Romanian Research and Innovation Ministry, through Program 1 - Development of the national researchdevelopment system, Sub-Program 1.2 - Institutional performance - Projects for financing excellence in RDI, contract no. 16PFE and by Contract 5N/07.02.2019.

\section{REFERENCES}

1. M. Asadi; Sugar Beet Handbook, John Wiley\&Sons Inc., Hoboken, New Jersey, 2006.

2. E. Evans; U. Messerschmidt; J. Anim, Sci. Biotechnol., 2017, 8, 1-10.

3. C. Ibáñez; M.C. López; P. Criscioni; C. Fernández; Anim. Prod. Sci., 2015, 55(1), 56-63.

4. M. Münnich; F. Klevenhusen; Q. Zebeli; J. Sci. Food and Agric., 2018, 98(3), 991-997.

5. M. Münnich; R. Khiaosaard; F. Klevenhusen; A. Hilpold; Q. Zebeli; Anim. Feed Sci. Tech., 2017, 224, 78-89.

6. A.P.A. Monteiro; J.K. Bernard; J.R. Guo; X.S. Weng; S. Emanuele; R. Davis; G.E. Dahl; S. Tao; J. Dairy Sci., 2017, 100(2), 1063-1069.

7. A. Jokić; Z. Zavargo; N. Lukić; B. Ikonić; J. Marković; J. Dodić; J. Grahovac; J. on Process and Energy in Agri., 2013, 17(1), 24-30.

8. L. Mogensen; T. Kristensen; Acta. Agric. Scand. (A), 2003, 53, 86-96.

9. P. Melendez, P.J Pinedo; J. Appl. Anim. Res., 2015, 43(3), 261-265.

10. E.M. Nagy; C. Coța; N. Cioica; Z. Gyorgy; T. Deac; Proceedings INMATEHAGRICULTURAL ENGINEERING Conferences, 2019, 112, 03023.

11. L. Yang; Z. Hu; L. Yang; S. Xie; M. Yang; INMATEH - Agricultural Engineering, 2018, 55(2), 53-62.

12. T.Y. Tende-Akintunde; G.O. Ogunlakin; J. Food Sci. Technol., 2013, 50(4), 705713.

13. A. Ghirisan; S. Dragan; C. Cota; E.M. Nagy: V. Miclaus; Studia UBB Chemia, 2018, 63(2), 53-62.

14. E.K. Akpinar; S. Toraman; Heat Mass Trans., 2015, 8(2), 110-123.

15. I. Doymaz, Energy Conv. and Manag., 2012, 56, 199-205.

16. D.G. Overhults; H.E. White; H.E. Hamilton; I.J. Ross; Trans. of ASAE, 1973, 16, 112-113.

17. S.M. Henderson; Trans. of ASAE, 1974, 17, 1167-1172.

18. E.K. Akpinar; J. Food Eng., 2006, 73(1), 75-84.

19. A. Ghirisan; S. Dragan; Studia UBB Chemia, 2013, LVIII(2), 35-42. 